\title{
JAMUR ENDOFITIK YANG DIISOLASI DARI BUNGA ANDROGRAPHIS PANICULATA (SAMBILOTO) SEBAGAI SUMBER SENYAWA ANTIBAKTERI
}

\author{
Rani Aulia Suhanah ${ }^{1}$, Suryelita Suryelita ${ }^{*}$, Sri Benti Etika ${ }^{1}$, Mariam Ulfah ${ }^{2}$, Riga \\ Riga $^{1}$ \\ ${ }^{1}$ Jurusan Kimia, Fakultas Matematika dan Ilmu Pengetahuan Alam, Universitas \\ Negeri Padang, Jalan Prof. Dr. Hamka, Air Tawar Barat, Padang 25132 \\ ${ }^{2}$ STIKES Muhammadiyah Cirebon, Jl. Kalitanjung No.14-18 A, Harjamukti, Kec. \\ Harjamukti, Kota Cirebon 45143 \\ *:elthaher@gmail.com
}

\begin{abstract}
ABSTRAK
Pendahuluan. Tumbuhan Andrographis paniculata (Sambiloto) memproduksi beragam metabolit sekunder dengan berbagai aktivitas biologi, termasuk antibakteri. Selain dari tumbuhan alami, potensi senyawa antibakteri dari tumbuhan A. paniculata dapat dieksplorasi dari jamur endofitiknya. Tujuan dari penelitian ini adalah melakukan kajian terkait potensi jamur endofitik yang berkolonisasi dalam jaringan bunga tumbuhan $A$. paniculata. Metode. Metode penelitian adalah eksperimen dengan tahapan penelitian ini terdiri dari isolasi, kultivasi, ekstraksi, uji antibakteri dan uji kandungan metabolit sekunder dari jamur endofitik pada bunga tumbuhan A. paniculata. Hasil. Hasil uji aktivitas antibakteri terhadap ekstrak EtOAc jamur BS-1 yang diisolasi dari bunga tumbuhan A. paniculata menunjukkan kemampuannya dalam menginhibisi pertumbuhan semua bakteri uji pada konsentrasi 1\%, 3\%, dan 5\%. Kesimpulan. Ekstrak EtOAc jamur BS-1 mempunyai potensi sebagai sumber senyawa antibakteri.
\end{abstract}

Kata kunci: Andrographis Paniculata, Antibakteri, Jamur Endofitik

\begin{abstract}
Andrographis paniculata (Sambiloto) is reported to produce secondary metabolites with various biological activities, including anti-bacteria. In addition to natural plant, the potential antibacterial compounds from the A. paniculata can be explored from its endophytic fungus. The purpose of this research was to study the potent of endophytic fungus colonized with the flowers of A. paniculata. The steps of this research were isolation, cultivation, extraction, antibacterial testing, and screening of secondary metabolites from endophytic fungus derived from A. paniculata flowers. The results of the antibacterial activity of the EtOAc extract from fungus BS-1 isolated from flowers of A. paniculata showed its ability to inhibit the growth of all tested bacteria at concentration of 1\%, 3\%, and 5\%. The EtOAc extract of fungus BS-1 has potential as a source of antibacterial compounds.
\end{abstract}

Keywords: Andrographis paniculata, Antibacterial, Endophytic fungus PENDAHULUAN 
Salah satu permasalahan dunia kesehatan yang cukup mengkhawatirkan dalam beberapa dekade terakhir ini adalah resistensi obat terhadap berbagai jenis mikroba. Permasalahan ini dipicu oleh berbagai penyebab, seperti konsumsi antibiotik yang tidak sesuai ketentuan dan terjadinya mutasi bakteri resisten secara alami (1). Untuk mengatasi persoalan ini, pencarian sumber alternatif yang dapat menghasilkan metabolit sekunder aktif sangat diperlukan. Salah satu sumber yang potensial dalam memproduksi senyawa bioaktif adalah jamur endofitik.

$$
\text { Jamur endofitik adalah }
$$
mikroorganisme yang hidup secara berkolonisasi dalam hampir semua jaringan tumbuhan, seperti akar, bunga, daun, buah, dan ranting $(2,3)$. Hubungan antara jamur endofitik dengan tumbuhan inangnya adalah simbiosis mutualisme. Jamur endofitik akan memproduksi berbagai metabolit sekunder dengan beranekaragam struktur dan kerangka dalam membantu tumbuhan inangnya untuk menghadapi serangan dari luar $(4,5)$. Beberapa golongan metabolit sekunder yang pernah dilaporkan dari jamur endofitik antara lain alkaloid, steroid, terpenoid, dan senyawa turunan fenolik dengan beragam aktivitas biologi $(6,7)$.

Total estimasi jamur endofitik yang ada di dunia adalah sekitar satu juta spesies dan baru $10 \%$ yang telah dilakukan kajian fitokimianya (8). Dengan demikian masih banyak spesies jamur endofitik yang belum dieksplorasi kandungan kimianya. Salah satu tumbuhan yang berpotensi sebagai inang bagi jamur endofitik adalah tumbuhan $A$. paniculata atau yang dikenal dengan nama sambiloto. Tumbuhan A. paniculata telah banyak dimanfaatkan secara tradisional untuk mengobati berbagai penyakit, seperti pilek, radang amandel, radang usus dan demam $(9,10)$. Fakta etnofarmakologi ini mengindikasikan bahwa jamur endofitik yang berasosiasi dengan tumbuhan A. paniculata akan menghasilkan metabolit sekunder dengan berbagai bioaktivitas, termasuk antibakteri dan sitotoksik. Kajian terkait kandungan kimia dari jamur endofitik yang hidup dalam daun tumbuhan A. paniculata telah 
pernah dilaporkan sebelumnya (11). Akan tetapi studi antibakteri dari jamur endofitik yang berasosiasi dengan bagian bunga tumbuhan $A$. paniculata baru pertama kali dilaporkan pada penelitian ini. Berdasarkan hal tersebut, tujuan penelitian ini adalah melakukan studi terkait potensi jamur endofitik yang berasosiasi dalam jaringan bunga tumbuhan $A$. paniculata sebagai sumber senyawa antibakteri.

\section{METODE PENELITIAN}

\section{Inokulasi Jamur Endofitik}

Tumbuhan A. paniculata diperoleh dari Kelurahan Tabing Banda Gadang, Kecamatan Nanggalo, Padang pada Bulan Januari 2021. Selanjutnya, bunga segar tumbuhan A. paniculata berukuran $2 \times 2 \mathrm{~cm}$ dialiri dengan air bersih untuk membersihkan permukannya. Bunga tersebut kemudian dilakukan sterilasi permukaan dengan merendamnya dalam larutan etanol $70 \%$ selama 45 detik dan larutan $\mathrm{NaOCl} 3,5 \%$ selama 30 detik. Sterilisasi permukaan ini bertujuan untuk membunuh mikroba epifit yang ada di bunga $A$. paniculata. Bunga yang telah disterilkan ini kemudian ditempelkan pada media padat PDA sebagai kontrol negatif. Bunga selanjutnya dipotong menjadi berukuran $1 \times 1 \mathrm{~cm}$ untuk kemudian diinokulasi di atas media padat PDA dan diinkubasi pada suhu $28{ }^{0} \mathrm{C}$. Setelah 7 hari, jamur endofitik yang tumbuh di sub-kultur ke media padat lainnya sehingga diperolah isolat tunggal jamur endofitik. Jamur endofitik dengan kriteria morfologi tertentu dipilih untuk dilanjutkan kajian fitokimianya (12).

Optimasi Waktu Kultivasi Jamur Endofitik

Isolat tunggal jamur endofitik dilakukan optimasi terkait waktu kultivasi optimum jamur dalam memproduksi metabolit sekunder. Potongan $2 \times 2 \mathrm{~cm}$ jamur endofitik yang tumbuh pada media padat dimasukkan ke dalam enam Erlenmeyer $250 \mathrm{~mL}$ yang berisi media nasi. Dua erlenmenyer pada masing-masing minggu kedua, ketiga dan keempat dipanen dan diekstraksi dengan pelarut etil asetat sehingga didapatkan ekstrak EtOAc. Ekstrak EtOAc dianalisis berdasarkan massa 
yang diperoleh untuk menentukan waktu kultivasi optimumnya.

\section{Kultivasi dan Ekstraksi Jamur Endofitik}

Isolat tunggal jamur endofitik dikultivasi pada Erlenmeyer $250 \mathrm{~mL}$ yang berisi $100 \mathrm{~mL}$ media nasi dan diinkubasi pada suhu $28{ }^{0} \mathrm{C}$. Setelah waktu kultivasi optimumnya, fermentasi jamur endofitik dipanen dan diekstraksi dengan etil asetat sebanyak tiga kali sehingga diperoleh ekstrak pekat EtOAc. Ekstrak EtOAc ini selanjutnya digunakan untuk uji aktivitas antibakteri dan uji kandungan metabolit sekunder.

\section{Uji Aktivitas Antibakteri Ekstrak}

\section{Jamur Endofitik}

Uji aktivitas antibakteri dari ketiga ekstrak jamur endofitik dilakukan dengan menggunakan metode difusi cakram. Alat yang digunakan pada tahapan ini adalah autoclave, laminar, cawan petri, gelas ukur, kertas cakram, jarum ose. Semua alat disterilisasi terlebih dahulu. Bahan yang digunakan antara lain media MHA, akuades, DMSO. Tiga bakteri yang digunakan pada penelitian ini adalah Escherichia coli, Staphylococcus aureus, dan Streptococcus pyogenes. Sebanyak 20 $\mu \mathrm{L}$ masing-masing ekstrak dengan konsentrasi 1\%,3\%, dan 5\% (pelarut: DMSO), kontrol positif dan kontrol negatif diteteskan pada kertas cakram yang terletak diatas inokulan masingmasing bakteri uji. Kontrol positif yang digunakan adalah amoksilin. Setelah diinkubasi 1x24 jam, aktivitas antibakteri masing-masing ekstrak diukur dan dinyatakan dalam zona hambat. Aktivitas antibakteri dilakukan sebanyak triplo. Proses uji dilakukan kondisi aseptik.

\section{Uji Kandungan Metabolit Sekunder}

\section{Terpenoid dan Steroid}

Ketiga ekstrak jamur BS-1 dimasukkan ke dalam tabung reaksi yang berbeda. Masing-masing tabung reaksi ditambahkan amoniakkloroform dan $\mathrm{H}_{2} \mathrm{SO}_{4} 2 \mathrm{~N}$. Campuran ini dikocok dengan kuat dan kemudian didiamkan hingga terbentuk dua lapisan. Lapisan bawah diletakkan pada plat tetes, dibiarkan menguap dan ditambahkan asam asetat anhidrat dan $\mathrm{H}_{2} \mathrm{SO}_{4}$ p.a. Hasil positif steroid memberikan warna 
hijau-biru dan hasil positif terpenoid memberikan warna merah.

\section{Alkaloid}

Lapisan atas pada uji seroid/terpenoid diatas dipindahkan ke tiga tabung reaksi. Ke dalam masing-masing tabung reaksi secara berurutan ditambahkan pereaksi Dragendorf, pereaksi Mayer dan pereaksi Wagner. Hasil positif uji alkaloid pada ketiga pereaksi memberikan endapan coklat, endapan putih dan endapan jingga.

\section{Senyawa Fenolik}

Ketiga ekstrak organik jamur BS-1 dimasukkan ke dalam plat tetes, lalu ditambahkan larutan $\mathrm{FeCl}_{3} 1 \%$. Hasil positif senyawa fenolik memberikan warna merah muda.

\section{HASIL DAN PEMBAHASAN}

Penelitian ini bertujuan menggali potensi jamur endofitik dari bagian bunga tumbuhan A. paniculata (sambiloto) sebagai sumber potensial senyawa antibakteri. Pemanfataan tumbuhan A. paniculata sebagai obat tradisional untuk berbagai penyakit dijadikan dasar dalam pemilihan sampel pada penelitian ini. Hal ini didukung oleh fakta bahwa sifat etnofarmokologi suatu tumbuhan dipengaruhi oleh kemampuan tumbuhan tersebut dalam memproduksi senyawa biokatif. Studi terkait kemampuan ekstrak dan senyawa murni dari jamur endofitik berbagai tumbuhan inang dalam menghambat pertumbuhan bakteri sudah pernah dilaporkan sebelumnya. Akan tetapi kajian terkait kemampuan antibakteri jamur endofitik dari bunga A. paniculata belum pernah dilaporkan.

Tahapan pertama pada penelitian ini adalah mengisolasi jamur endofitik dari bagian bunga segar tumbuhan A. paniculata. Bunga A. paniculata ini dibersihkan dengan air mengalir untuk menghilangkan berbagai macam pengotor yang terdapat di permukaan bunga tersebut. Selanjutnya mikroorganisme pada permukaan bunga A. paniculata dibersihkan dengan dengan proses sterilisasi menggunakan etanol $70 \%$ dan $\mathrm{NaOCl}$ $3,5 \%$. Proses sterilasi ini bertujuan 
untuk memastikan bahwa jamur yang akan tumbuh pada media inokulan nantinya adalah jamur endofitik atau jamur yang berasal dari dalam jaringan bunga $A$. paniculata. Bunga yang steril tersebut diinokulasi di atas media agar PDA yang telah ditambahkan antibiotik. Setelah 7 hari, jamur yang tumbuh di sub-kultur ke media agar PDA lainnya sehingga diperoleh dua isolat tunggal jamur endofitik. Jamur endofitik dengan kode BS-1 dipilih untuk dilanjutkan pada proses berikutnya berdasarkan pengamatan morfologi jamur tersebut (12).

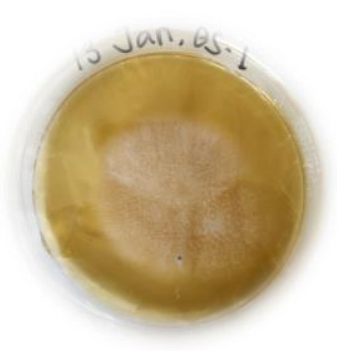

Gambar 1. Morfologi jamur BS-1

Jamur BS-1 (Gambar 1) memiliki ciri makroskopik sebagai berikut. Warna koloni dari jamur ini adalah putih dengan bentuk bulat serta membentuk koloni yang memusat. Permukaan koloni jamur BS-1 cukup kasar dan persebarannya tipis merata ke semua permukaan media. Permukaan bagian bawah dari jamur BS-1 adalah berbentuk koloni yang berwarna putih. Jamur dengan morflogi makroskopik seperti jamur BS-1 belum pernah dilaporkan dari tumbuhan A. paniculata.

Jamur BS-1 dari bunga $A$. paniculata selanjutnya dikultivasi skala kecil untuk menentukan waktu optimum jamur tersebut dalam memproduksi metabolit sekunder. Esktrak EtOAc jamur BS-1 pada minggu pertama, kedua, ketiga dan keempat dianalisis kandungan metabolit sekundernya berdasarkan massa ekstrak yang diperoleh. Metabolit sekunder diproduksi oleh jamur endofitik pada tahap stasioner, yaitu tahap dimana terdapatnya keseimbangan antara kecepatan pertumbuhan dan kematian sel. Tahap ini terjadi ketika nutrisi yang terdapat pada media mulai habis. Hal ini akan menyebabkan enzim-enzim yang berperan dalam produksi metabolit sekunder akan terakumulasi sehingga metabolit sekunder akan dihasilkan dalam jumlah lebih banyak. Hasil analisis menunjukkan bahwa waktu kultivasi optimum jamur BS-1 dalam 
menghasilkan senyawa adalah dua minggu. Selanjutnya massa ekstrak EtOAc pada minggu pertama, kedua, ketiga dan keempat dari jumlah kultivasi yang sama ditampilkan pada Tabel 1.

Tabel 1. Massa ekstrak EtOAc (mg) pada minggu pertama, kedua, ketiga, dan keempat kultivasi

\begin{tabular}{|c|c|c|c|c|}
\hline \multirow{2}{*}{ Jamur } & \multicolumn{4}{|c|}{ Minggu } \\
\cline { 2 - 5 } & 1 & 2 & 3 & 4 \\
\hline BS-1 & & & & \\
(Jamur & 15,3 & 25,3 & 24,6 & 24,0 \\
dari bunga & $\mathrm{mg}$ & $\mathrm{mg}$ & $\mathrm{mg}$ & $\mathrm{mg}$ \\
$\begin{array}{c}\text { A. } \\
\text { paniculata }\end{array}$ & & & & \\
\hline
\end{tabular}

Jamur BS-1 selanjutnya dikultivasi skala besar ke dalam 25 Erlenmeyer yang berisi media nasi. Kultivasi skala besar dilakukan untuk mendapatkan massa ekstrak dalam jumlah yang lebih banyak. Setelah dikultivasi selama tahap stasioner (dua minggu), jamur BS-1 dipanen dan diekstraksi menggunakan pelarut etil asetat. Hasil ekstraksi dipekatkan sehingga didapatkan ekstrak pekat EtOAc.

Ekstrak pekat EtOAc tersebut diuji aktivitas antibakterinya menggunakan metode difusi cakram (2). Uji aktivitas antibakteri ekstrak EtOAC dilakukan terhadap tiga bakteri uji, yaitu adalah E. coli, $S$. aureus, dan S. pyogenes. Konsentrasi ekstrak yang diujikan terdiri dari tiga variasi, yaitu $1 \%, 3 \%$ dan $5 \%$. Kontrol positif yang digunakan pada uji antibakteri ini adalah amoksilin. Uji aktivitas antibakteri ini dilakukan secara triplo dan hasil uji dinyatakan sebagai zona hambat yang ditampilkan pada Tabel 2.

Tabel 2 tersebut menunjukkan bahwa ekstrak EtOAc jamur BS-1 yang diisolasi dari bunga $A$. paniculata memiliki kemampuan dalam menginhisi pertumbuhan semua bakteri uji. Semakin tinggi konsentrasi ekstrak berkorelasi positif dengan kemampuannya sebagai agen antibakteri. Hal ini dikarenakan oleh kandungan senyawa aktif yang semakin besar. Meningkatnya kandungan senyawa aktif akan membuat kemampuan ekstrak dalam menginhibisi pertumbuhan bakteri uji juga semakin meningkat.

Tabel 2. Data zona hambat ekstrak EtOAc terhadap bakteri uji

\begin{tabular}{|c|c|c|c|c|}
\hline \multirow{2}{*}{$\begin{array}{c}\text { Bakteri } \\
\text { Uji }\end{array}$} & \multicolumn{4}{|c|}{ Diameter Zona Hambat* } \\
\cline { 2 - 5 } & $1 \%$ & $\mathbf{3 \%}$ & $\mathbf{5 \%}$ & $\begin{array}{c}\text { Kontrol } \\
(+)\end{array}$ \\
\hline
\end{tabular}




\begin{tabular}{|l|c|c|c|c|}
\hline E. coli & 5,67 & 6,00 & 6,67 & $8,67 \pm$ \\
& \pm & \pm 0 & \pm & 0,58 \\
& 0,58 & & 0,58 & \\
\hline S. aureus & 6,67 & 8,00 & 8,33 & $9,33 \pm$ \\
& \pm & \pm & \pm & 0,58 \\
& 1,15 & 2,65 & 1,53 & \\
\hline S. & 6,33 & 7,33 & 8,33 & $15,00 \pm$ \\
pyogenes & \pm & \pm & \pm & 1,73 \\
& 0,58 & 0,58 & 0,58 & \\
\hline
\end{tabular}

${ }^{*}$ Zona hambat \pm standar deviasi

Hasil positif uji antibakteri terhadap ekstrak EtOAc mengindikasikan terdapatnya metabolit sekunder yang memiliki potensi sebagai senyawa antibakteri. Selanjutnya ekstrak EtOAc diuji kandungan metabolit sekunder yang meliputi alkaloid, terpenoid, steroid, dan fenolik. Hasil uji kandungan kimia ekstrak organik ditampilkan pada Tabel 3. Mekanisme kerja metabolit sekunder golongan alkaloid dalam menginhibisi pertumbuhan bakteri adalah dengan mengganggu komponen penyusun peptidoglikan pada sel bakteri. Senyawa non fenolik seperti terpenoid memiliki aktivitas antibakteri dengan cara mengganggu proses pembentukan membran atau dinding sel. Hal ini menyebabkan dinding atau membran sel tidak akan terbentuk secara sempurna (13).

Aktivitas antibakteri senyawa fenolik dipengaruhi oleh lipofilisitas, sifat elektronik dan muatan polifenol yang dapat menghinbisi kerja enzim reverse transkripsi dan DNA topoisomerase $(14,15)$. Penelitian terkait metabolit sekunder yang berperan dalam aktivitas antibakteri pada ekstrak jamur BS-1 perlu dilanjutkan sehingga dapat melengkapi informasi terkait senyawa antibakteri dari jamur BS-1.

Tabel 3. Hasil uji kandungan metabolit sekunder ekstrak EtOAc jamur BS-1

\begin{tabular}{|l|c|}
\hline \multicolumn{1}{|c|}{ Uji Metabolit Sekunder } & Hasil Uji \\
\hline Terpenoid/Steroid & + \\
\hline Alkaloid & + \\
\hline Fenolik & + \\
\hline
\end{tabular}

\section{KESIMPULAN}

Hasil uji antibakteri dari ekstrak EtOAc jamur endofitik BS-1 yang diisolasi dari bunga A. paniculata terhadap tiga bakteri uji, yaitu E. coli, $S$. aureus, dan $S$. pyogenes menunjukkan bahwa ekstrak EtOAc tersebut memiliki kemampuan dalam menghambat pertumbuhan bakteri uji.

\section{UCAPAN TERIMA KASIH}

Penulis mengucapkan terima kasih kepada Lembaga Penelitian dan Pengabdian Masyarakat (LP2M) 
Universitas Negeri Padang dan Jurusan Kimia, FMIPA, Universitas

Negeri Padang atas bantuan dan dukungan selama penelitian berlansung.

\section{DAFTAR PUSTAKA}

1. Wang W, Arshad MI, Khurshid M, Rasool MH, Nisar MA, Aslam MA, et al. Antibiotic resistance: a rundown of a global crisis. Infect Drug Resist. 2018;1645-58.

2. Riga R, Happyana N, Quentmeier A, Zammarelli C, Kayser O, Hakim EH. Secondary metabolites from Diaporthe lithocarpus isolated from Artocarpus heterophyllus. Nat Prod Res. 2019;

3. Manganyi MC, Ateba $\mathrm{CN}$. Untapped potentials of endophytic fungi: A review of novel bioactive compounds with biological applications. Microorganisms. 2020;8(12):1-25.

4. Riga R, Happyana N, Hakim EH. Chemical Constituents of Pestalotiopsis microspora HF 12440. J Appl Pharm Sci. 2019;9(1).

5. Rustamova N, Bozorov K, Efferth T, Yili A. Novel secondary metabolites from endophytic fungi: synthesis and biological properties. Phytochem Rev [Internet]. 2020;19(2):425-48. Available from:

https://doi.org/10.1007/s11101
-020-09672-X

6. Schulz B, Haas S, Junker C, Andrée N, Schobert M. Fungal endophytes are involved in multiple balanced antagonisms. Curr Sci. 2015;109(1):39-45.

7. Toghueo RMK. Bioprospecting endophytic fungi from Fusarium genus as sources of bioactive metabolites. Mycology [Internet]. 2020;11(1):1-21. Available from: https://doi.org/10.1080/21501 203.2019.1645053

8. Jia M, Chen L, Xin HL, Zheng CJ, Rahman K, Han T, et al. A friendly relationship between endophytic fungi and medicinal plants: A systematic review. Front Microbiol. 2016; 7(JUN):1-14.

9. Utaminingrum $\mathrm{W}$, Nofrianti $\mathrm{N}$, Hartanti D. Ethnomedicinal survey of traditional antidiabetic plants in Baturraden and Sumbang. Medisains. 2020;18(2):43.

10. Silalahi M. Sambiroto (Andrographis paniculata) dan Bioaktivitasnya. 2020;3(1):2614-8064.

11. Munawar M, Muharni M, Ivantri I. Chemical Constituen from an Endophytic Fungus Aspergillus sp (SbD5) Isolated from Sambiloto (Andrographis paniculata Nees). Microbiol Indones. 2015;9(2):82-8.

12. Calvo AM, Wilson RA, Bok JW, Keller NP. Relationship between Secondary Metabolism and Fungal Development. Microbiol Mol Biol Rev [Internet]. 2002 Sep 
1;66(3):447 LP $\quad-\quad 459$. Available from: http://mmbr.asm.org/content/6 6/3/447.abstract

13. Kurniawan B, Ferly Aryana W. Cassia Alata L) For Inhibiting The Growth Of Bacteria. Escherichia Coli J Major [Internet]. 2015;4:101. Available from: http://juke.kedokteran.unila.ac .id/index.php/majority/article/ view/588

14. Bouarab-Chibane L, Forquet
V, Lantéri P, Clément Y, Léonard-Akkari L, Oulahal N, et al. Antibacterial properties of polyphenols: Characterization and QSAR (Quantitative structure-activity relationship) models. Front Microbiol. 2019;10(APR).

15. Kursia S, Aksa R, Nolo MM. Potensi Antibakteri Isolat Jamur Endofit dari Daun Kelor (Moringa oleifera Lam.). Pharmauho J Farm Sains, dan Kesehat. 2018;4(1):30-3. 